\section{AGM Minutes - 2007 Thirty-Sixth Annual Meeting}

The 36th Annual Meeting of the College was held at the Edinburgh International Conference Centre (EICC), Edinburgh, from 19 to 22 June 2007.

\section{Business Meeting}

The Business Meeting of the Royal College of Psychiatrists was held on Wednesday, 20 June 2007 and was chaired by the President, Professor Sheila Hollins. It was attended by 56 members of the College.

The minutes of the previous meeting held in Glasgow on Tuesday 11 July 2006 and published in the Psychiatric Bulletin, December 2006, were approved and signed.

The Registrar read out the obituary list of members who had died since the Winter Business Meeting, and a minute's silence was observed.

\section{Report from the President}

Welcome to this year's annual meeting. In particular I would like to welcome our Honorary Fellows and two of our past Presidents, Dr Mike Shooter and Professor John Cox.

I would like to start by paying tribute to all the College's Members and Fellows who have passed away over the past year and especially to Sir Martin Roth, the founding President of our College, who died at the end of last year.

Thanks to our Members and Fellows around the world, the work of the College's International Divisions continues to grow. I have been lucky enough to visit some of our International Divisions in the past year and to join some of their meetings.

I had an interesting visit to Kenya in March 2007 for the first meeting of our African Division, which was held as part of the World Psychiatric Association (WPA) regional meeting organised by the Kenyan Psychiatric Association. As well as meeting many African psychiatrists, Professor Hamid Ghodse and I met three College volunteers who have had placements in Nigeria, Malawi and Ethiopia. Two of these were trainees whose placements had been approved for training. There are increasing opportunities for both senior and trainee volunteers to work in many parts of the world (see http://www.rcpsych.ac.uk/ college/boardofinternationalaffairs/ seniorvolunteersprogramme.aspx for more information)

In February I visited Pakistan, attending the first international conference of the
WPA Section on Developing Countries, which was held in Lahore. The South Asian Division of the College, chaired by Professor Arun Ahmad, was particularly active. I met local politicians and administrators with local psychiatrists to raise awareness of the mental health issues arising from trauma following disasters including a tour of the earthquake zone. I am particularly grateful to Dr Afzal Javed for arranging such an informative visit.

In November 2006 I attended the XIV World Congress of Inclusion Internationa in Mexico thus ensuring some continuing involvement in my own specialism during my presidency - and contributed a daylong symposium on violence and vulnerability in the lives of people with learning disabilities with contributions from Lebanon, Israel, South Africa and Mexico as well as the UK.

I will now turn to constitutional matters. The constitution of College Committees, Faculties, Sections, and Special Interest Groups is set out in the Bye-laws and Regulations, which can only be changed at the Annual General Meeting (AGM), subject to Privy Council approval. Constitutional changes, streamlining and modernising the committee structure and increasing efficiency of College processes, were introduced gradually throughout the year. The elected officers had an Away Day in January and the Central Executive Committee (CEC) had an Away Day in May. These were extremely helpful in looking at the effectiveness of our structures and governance arrangements to support our priorities as an organisation.

The CEC was established in September last year, replacing Council and the Executive and Finance Committee. CEC is the principal decision-making body within the College and has full management and control of the College and its affairs. Full members of CEC are the Trustees of the College.

The Education, Training and Standards Committee (ETSC) was introduced, replacing the Court of Electors. The title of this new committee reflects its modern role and better describes its functions. ETSC reports to $C E C$, ensuring that our important educational work is firmly placed in the core of the College.

The Psychiatric Trainees Committee (PTC) replaces the Collegiate Trainees Committee. The PTC comprises both 'Pre-Membership' and 'Post-Membership' psychiatric Trainees. This new class of association offers many more benefits than the former category of 'Inceptorship'.

The Special Committee on Human Rights was established to provide advice on matters relating to human rights and mental health. This recently established Special Committee is to be the College's source of expertise and experience on all matters pertaining to human rights in relation to mental health and psychiatry in the UK and elsewhere.

I have set up three short-life scoping groups - the first chaired by Dame Fiona Caldicott to review the place of psychotherapy within psychiatry, and the second, chaired by Baroness Helena Kennedy (as an Honorary Fellow), on Risk Assessment and Management across the whole of psychiatry. The third group will look at Emergency Psychiatry and is jointly chaired by Professor Sir George Alberti and myself. All three are due to report and advise in the autumn.

I am also planning to establish a scoping group to review the College preparedness for the challenges facing psychiatry in the 21st Century and I am hoping another eminent Honorary Fellow will chair this.

The newly established Academic Faculty draws members from all specialties. The officers of this Faculty help to discern the College's priorities and future work plan with respect to both research and medical education.

In February it became clear that there were serious problems with the Medical Training Application Service (MTAS), the national selection process established to appoint doctors to Modernising Medical Careers (MMC) run through training posts. The system ran into serious trouble with legitimate complaints about a lack of posts, poorly designed recruitment forms and technical failures of the online application system. I agreed to join the Review Group set up to try and find some solutions. CEC welcomed this, feeling that our particular needs in psychiatry could best be met by my participation. Unfortunately, the end of this year's job allocations is still not in sight.

I am still advocating for adequate arrangements for doctors to swap to a Deanery closer to home if they have been offered jobs a long way away. I have also tried to advocate for international medical groups caught up in this debacle. The system has caused untold stress to thousands of doctors and families, as well as employers. We need to take lessons from this fiasco on board, and ensure that any system which replaces MTAS does so effectively, sensitively and appropriately, and is piloted extensively. The pressures on individuals, consultants and trainees have been unprecedented. I will be giving evidence to the Tooke review of MMC in July and I am confident that there will be significant changes to the structure of training and selection into training.

A priority at the CEC Away Day was to think about the psychiatrist of the future. New Ways of Working is changing the way service is delivered, while Modernising 
Medical Careers and PMETB are influencing postgraduate psychiatric training. It is imperative that all those involved in these changes work together to ensure that high quality training today produces 'fit for purpose' high quality Consultant Psychiatrists tomorrow.

Dr Tony Zigmond has continued to lead on the Bill as Honorary Vice-President and we are extremely grateful to him for his tireless work, which has involved spending innumerable hours in the Parliament. He has ensured that the College and in particular the Parliamentary Committee, CEC, the President and the Registrar understand what is happening at each stage of the Parliamentary process. He has also played an important role in the Mental Health Alliance ensuring that our commitment to working closely with patient and carer organisations is demonstrable. The third reading took place yesterday and you will know that some major concessions were achieved, particularly with respect to age appropriate services and therapeutic benefit.

A network of medical directors was established last year. This was welcomed and supported by medical managers in the NHS and private sector. Dr Peter Kennedy, the Vice-President responsible for management, leads this work.

Dr Roger Banks, the Vice-President responsible for Primary Care, is leading a new stream of work in partnership with the Royal College of General Practitioners.

Dr Aileen O'Neill, Policy Analyst, is now in post at Belgrave Square and in addition to providing policy briefings for elected officers she has helped to set up a scoping group, chaired by Baroness Helena Kennedy, on risk assessment and risk management. The first stage of this work will focus on risk to others.

Chris Fitch, College Research Fellow, is in post at the CRTU and his first priority is to improve our effectiveness in consulting members on topical issues. Our first online survey was launched last month and a representative sample of members is now being sought for rapid opinion testing as need directs.

Work continues on the Images of Psychiatry campaign, which aims to raise awareness among young people of mental health issues and of psychiatry, reduce the stigma associated with mental health problems, and ensure that user and carer issues are core to psychiatry as a discipline.

The CEC has appointed Bell Pottinger, a communications consultancy, to help us review and develop our media skills. The timing of this coincided with considerable publicity about mental illness surrounding the Mental Health Amendment Bill (England and Wales). Bell Pottinger has enabled the College to use the opportunity this afforded to raise other mental health issues. Bell Pottinger will also advise on improving relations with more specialist media, for example with the ethnic media, to address this key objective in the College's race equality action plan. Training days have been taking place with psychiatrists from several Divisions and their interim report and recommendations will be presented to the next CEC meeting.

I would like to finish by thanking all the current Officers and College staff for all their hard work. I would also like to thank those Chairs and Directors who are demitting office for everything they have done for the College. In the autumn nominations will be sought for a new Dean and new President to take up office at the AGM in 2008

\section{Report from the Dean - Professor Dinesh Bhugra}

What a year it has been! It was indeed, to paraphrase Dickens, the worst of times and the best of times. My heart goes out to all the trainees and their families and friends who for no fault of their own were caught in the middle of a major policy and implementation disaster by the government in their attempts to push through the MMC changes too quickly. It makes me extremely sad that the MTAS fiasco has left many trainees disenchanted with the profession. The government and the civil servants who pushed through an agenda without any serious consideration for the outcome of their actions were advised publicly and privately by this College and others about the need for a proper piloting and gradual introduction of all the changes. But, for reasons best known to them, they chose to go for the big bang and, unfortunately, this has really come back to haunt them. I would really like to reassure Trainees, Members and Fellows that over the last year my colleagues and I have worked tirelessly to advise the powers-that-be about the issues that are crucial to high quality Psychiatric training. However, last year's failures in postgraduate training are part of a larger active programme of deprofessionalisation of doctors by this government and unfortunately not just the trainees and the rest of the medical profession but also the patients might have to pay the price. I, maybe naively, hope that the government has at least learnt a lesson about the significance of the Colleges and will be more willing to listen to us in the future. Early signs indicate that this might happen but I have been around long enough and am acutely aware of the short-term memory of politicians. In the next few years we have no option but to force our agenda of high quality training harder than ever before and with your help I am confident that we will succeed.

Amid all this confusion and chaos, we have remained focused on raising the standards in education and training and modernising the examinations and assessments that support this.

In my fourth year as Dean I believe we have made substantial progress in these areas. I am pleased to say that we did win many victories such as not reducing the duration of training in spite of MMC insistence on reduction.

Our new curriculum for psychiatric training had already received full PMETB approval and we were the second College to do so.

During the past year, under the leadership of Dr Andy Brittlebank who has been seconded by his trust to the College, we have continued to pilot the introduction of Workplace Based Assessments into the specialist training years. Andy's experience and enthusiasm has been invaluable and has enabled us to refine the tools we shall use from August 2007. With 17 sites and over 600 trainees participating in the pilot study we have substantial data to ensure that we do not introduce any change without taking on board the lessons from the piloting, unlike MTAS!! These tools have been mapped to the curriculum. Two weeks ago our assessment programme, which these tools form a part of, received PMETB's approval. I am delighted to be able to report that we are the first College to obtain PMETB approval of such assessment programme and in doing so we have set the bar for other Colleges in the UK. Gareth Holsgrove as educational advisor deserves our thanks. Many tutors and trainers have been advising me on the development and delivery of Workplace Based Assessments and without naming all of them I remain very grateful to them.

While I am immensely proud of this achievement, I am also fully aware that the task will only be completed when the new curriculum and assessment programme are successfully implemented for specialty trainees in the new runthrough programmes and Fixed Term Specialist Training (FTST) appointments. As a first step towards successful implementation, since April we have been running workshops throughout the UK on Workplace Based Assessments so that consultants and trainees alike will be ready for the new forms of assessment when they are introduced. These have been very successful and I am grateful to those who have both led and undertaken this work. During this period we have run over 20 workshops and trained over 450 trainers. This is in addition to a large number of workshops conducted as part of the piloting process where over 100 trainers were trained.

Prior to starting the pilots Amit Malik, Chair of the Psychiatric Trainees' Committee, Robert Jackson, Head of Postgraduate Education and myself had travelled extensively around the country to keep Fellows, Members and Trainees 
informed about the rapidly evolving and ever changing implications and requirements of Modernising Medical Careers.

In an admirable and painstaking manner, the Chief Examiner, Professor Anthony Bateman, has led the work on changes to the MRCPsych examination. The new College examination and assessment programme combine workplace based assessments with formal examinations to deliver a robust assessment structure with flexibility and transparency while at the same time ensuring that the high standards of the MRCPsych are maintained. We have removed the clear distinction between MRCPsych Part I and Part II, instead opting for a more modular approach realised through a series of written papers and a clinical examination. There are three knowledge-based papers, Paper 1, Paper 2, Paper 3, and a clinical examination in the form of Objective Structured Clinical Examination (OSCE). The latter will comprise 20 stations of complex OSCEs where all specialties of psychiatry will be tested. Each component requires candidates to have achieved certain competencies at specified levels in their workplace based assessments. Success in the MRCPsych examinations will remain key for trainees to progress and to achieve a Certificate of Completion of Training in psychiatric specialties. Extensive pilot studies are underway to ensure that various components of examination work well together and are fit for purpose.

Dr Siva Kumar demits office today as Associate Dean. Siva has provided huge personal support to me during his time in office and for this and his untiring efforts on behalf of the College, I wish to record my gratitude and that of those who have worked with him over the last few years. Siva has chaired the Equivalence Committee and the Specialist Training Committee in his quiet and unflustered way and his work in these areas will be sadly missed.

Siva is succeeded as Associate Dean by Laurence Mynors-Wallis whose prime responsibility will be for the work relating to the re-certification of specialists. The Chief Medical Officer for England published his long awaited report 'Good Doctors, Safer Patients' nearly a year ago; this was followed by the White Paper 'Trust Assurance and Safety: The Regulation of Health Professionals in the 21st Century'. We are now clearer about the work Laurence will lead on in relation to the recertification of specialists in psychiatry. Laurence will be working closely with the new Director of CPD, J.S. Bamrah. Jas took over from Joe Bouch who did a great deal to raise the profile of CPD among Members. Now that the White Paper is published Jas will take forward the review of CPD policy to ensure it fits in with what is required.
We have re-configured the education committee structure to make it more relevant to the present time and to ensure that, when necessary, we may respond quickly to consultations from PMETB and other bodies. Nick Brown, Associate Dean for training, will lead the Assessment, Quality Assurance and Curriculum Committees. One of his first tasks is to respond to PMETB's consultation on the Quality Assurance Framework while another is to review, with the Faculties and their Education Committees, the curriculum. Nick is most definitely the best person to lead on these and the College hopes it can continue to benefit from his dedication and commitment to postgraduate psychiatric training in the UK. Nick has contributed hugely to the College's work in the areas of education and training often under extremely difficult circumstances and often against extremely tight deadlines and for this I am very grateful.

There is more work to be done in other areas of education and training. Responsibility for the College's association with non-consultant career grades today passes from the Registrar to me. I have asked Professor Gregory O'Brien, an Associate Dean, to lead both the Affiliates' and SAS Members' Committee and the Equivalence Committee. I am sure Gregory will continue the excellent work started by his predecessors and that he will now move them to the next level.

Anne Bird and Sally Pidd have respectively continued to support examinations and workforce planning in their efficient and hard working manner and I would like to record my personal thanks to them.

Before finishing I must pay tribute to Amit Malik, Chair of the Psychiatric Trainees' Committee. Amit has not only led the Committee with energy, verve, style and great enthusiasm but has also represented the interests of trainees in many other fora. He has been a huge support, a person to bounce ideas off and a source of strength throughout his term of office.

This has been a difficult year in many ways but despite that we have achieved much. I would like to place on record my thanks to Vanessa Cameron, Robert Jackson, Fauzan Palekar and their staff for the unqualified support they have continued to provide to the Associate Deans and me over the past year.

Finally, I would like to thank all the Trainees, Members and Fellows who have continued to place their faith in the College and in me. I want to reassure you all that I will not allow the important lessons learnt from this year to be forgotten as I continue the work of further raising the standards of education and training within psychiatry and further policy development in the UK.
Report from the Editor - Professor PeterTyrer

The past year has been one of both consolidation and change for the Publications Department. The British Journal of Psychiatry has maintained its position as the leading psychiatric journal outside the United States with a gradually rising impact factor, and is increasingly popular with authors of original manuscripts, a negative consequence of which is that most of these manuscripts are rejected. The Psychiatric Bulletin, Advances in Psychiatric Treatment and International Psychiatry are all prospering and we will shortly be including Advances in Psychiatric Treatment as part of the CME programme for North American psychiatrists. However, we also note with some sadness that Alan Lee, the editor of Advances in Psychiatric Treatment for the past 8 years, has now retired after a very productive period. He has been replaced by Dr Joe Bouch. Professor Tom Fahy will be stepping down as the similarly successful editor of Psychiatric Bulletin in December this year. The post has been advertised and we will be interviewing shortly.

The website of the College has been voted as one of the top three sites on mental health matters in the country. This website also advertises our new podcasts, in which Professor Raj Persaud interviews authors of recently published papers in the Journal. This new venture has spread the influence of our original papers considerably.

A 'redesign team' of Andrew Morris, Tom Fahy, Mike Crawford, Sukhi Shergill and Kiriakos Xenitidis have proposed a new cover design and format for the British Journal of Psychiatry and this will be launched in 2008. We hope that it will make the Journal more lively and topical. We will be including additional short pieces of general interest under the supervision of our new Executive Contents Editor, Professor Robert Howard. The book programme is going well, but we have to report the sad passing of Gaskell Books and its replacement by RCPsych Publications, which although less euphonious, chimes with the increasing use of the internet in communication. We also have to report a set of firsts; the first book we have published weighing over $2 \mathrm{~kg}$ (Seminars in General Psychiatry, edited by George Stein and Greg Wilkinson) $(2.5 \mathrm{~kg}$ ), our first venture into mass publishing - The Mind A User's Guide (edited by Raj Persaud to be published on 4 July by Transworld (Bantam Press)), and our first book to have sold all its copies within 6 months (the revised edition of Fish's Psychopathology by Patricia Casey and Brendan Kelly).

But against the backdrop of all this excitement we must not forget the 
central directors of our work, with Dave Jago and Andrew Morris leading an excellent team of Moira Barry, Julia Burnside, Anne-Louise Clayton, Carrie Davis, Simonne Erian, Michael Foord, Yona Friedman, Martin Georgiev, Mina Kupfermann, Jonica Love, Lynnette Maddock, Amanda May, Connie Sinclair and Daniel Tomkins. It is a good team and I have not seen any yellow or red cards produced recently, so I think it is doing well. And as the referee has just blown his whistle for the end of the game I can give you the score: Publications Team United 2, Biased Journalism Rangers 0 . One of the reasons why Biased Journalism Rangers have no goals is that the College allows the Publications Department to get on with its job without any interference, and for that we remain exceedingly grateful.

\section{Report from the Registrar -} Professor Sue Bailey

The Registrar announced the Election Results:

\section{COLLEGE OFFICERS}

Honorary College Archivist (new Post) Dr Fiona Subotsky

\section{Associate Dean \\ Dr Laurence Mynors-Wallis \\ Director of Conferences \\ Dr Helen Miller \\ Director of CPD \\ Dr J. S. Bamrah}

Director of International Affairs

Professor Rachel Jenkins

FACULTIES AND SECTIONS

Eating Disorders Faculty (new Section)

Dr Ulrike Schmidt

General \& Community Faculty

Dr Michele Hampson

\section{DIVISIONS}

Irish Division

Dr Consilia Walsh

South West Division

Dr Adrian James

\section{SPECIAL INTEREST GROUPS}

Management Special Interest Group

Dr R. S. Deo

Private and Independent Practice

Dr Lisa McClelland

Psychopharmacology Special Interest

Group

Dr David Baldwin

Women in Psychiatry Special Interest

Group

Dr Fiona Mason

\section{COMMITTEES}

Special Committee on Professional Governance and Ethics

Dr Elizabeth Fellow-Smith

Crossing the Professional/Technical Practice Divide: For all Trainees, Affiliates,
Members and Fellows, both nationally and internationally, the past 12 months have been challenging times beyond those that could have been predicted at the last AGM. I have endeavoured as Registrar to support the whole Membership, Central Executive Committee and my fellow elected Officers.

This has certainly been a time to sustain a positive belief in the art of professionalism, over the current move towards technician practitioners.

While accepting absolutely the benefits to patient care of quality service delivery in the context of clinical governance, the risk of clinical practice as a technical matter is the risk of service delivery through pre-determined means to achieve preset goals. Failure to achieve becomes the 'fault' of staff involved. In excess of 40 regulatory bodies currently govern healthcare. Professional practice at its heart is the exercise of discretion in situations of uncertainty.

As professionals we have long known the practice at the edge of uncertainty and in the arena of complexity, where not everything can be known. Judgement is central to practice - protocols assist. Quality lies within each professional, working in teams, but it should be measurable. The quality of service delivery should always be our priority. Professional self-regulation is still needed, recognising the context of performance management. Development achieves high quality, in the context of regulations that should be:

- Proportionate

- Accountable

- Consistent

- Transparent

- Targeted

Professional education must remain at the heart of our College and our clinical practice.

This work I have undertaken in collaboration with staff from the College and with the Deputy and Associate Registrars and the Director of Public Education. To all, I give my thanks.

- Membership

- College Library and College Archives

- Psychiatrists Support Service

- Public Education/External Affairs

- Users and Carers

- Policy

Membership Section: The Registrar is the keeper of the list and thus is the College Officer with ultimate responsibility for the security and accuracy of the membership database, the release of information there from and its use for management information and as the channel of communication with members. My other responsibilities in this area include:
- Provision of mailing data for Research projects carried out by staff colleagues, SpRs and more senior College members, including liaison with the Faculties to review and assess the proposed projects. Since July 2005 we have provided data for about 50 such exercises.

- Resolution of individual queries from patients and carers, other medical and non-medical professionals and from organisations who need advice on 'the right psychiatrist to help'.

- Consideration of Data Protection issues and the balance to be struck between protecting the privacy of our members and restraining unduly the valid work of College office holders.

- Working with colleagues in the IT and website areas to introduce and expand mass emails and introduce the new College and CETC e-newsletters.

College Library and College Archives: The College library continues to support professional learning, education and research by providing high quality, integrated and innovative services. It enables members to acquire excellent information through providing literature searches and document delivery. Usage of library services continues to increase as more resources become available electronically. The physical library is being enhanced as a place for members to relax when they are visiting the College.

The College Archivist is responsible for providing a records and archives management service. The Archives recently acquired the Heritage Documentation Management System. This is a software which is specially designed to manage archives and records according to international standards. The system is now being used to create a database which will eventually be accessed through the College website. Further development of Heritage will provide better tracking for the multiple documents that arrive at and emanate from the College to better enable us to shape policy. The Archivist is also preparing to launch the Adopt-aBook programme, which is aimed at raising funds for the repair and conservation of the antiquarian book collection.

We are delighted that Fiona Subotsky will be the College Honorary Archivist.

Psychiatrists' Support Service: The Psychiatrists' Support Service was recommended by Council in 2005. Since then, an Associate Registrar (Dr Pete Snowden) was appointed in November 2006 to lead the service. A Psychiatrists' Support Service Manager, Diana Chan was appointed in December 2006 to manage the service on a day-to-day basis.

The new Support Service is for College members and associates and will launch formally at this Annual General Meeting. 
7?

columns
The service is a confidential advisory and signposting telephone helpline available for doctors in difficulty over issues such as:

- Addictions

- Bullying and harassment

- Career pathways

- Examinations

- Exclusion

- GMC/NCAS involvement

- Health problems

- Homicide inquiries

- Internal and external reviews

- Serious clinical incidents

- Training

- Whistle-blowing

Psychiatrists contacting the service may be signposted to another appropriate organisation or service. Some doctors may benefit from focused support from a senior College member of the Psychiatrists' Support Service Committee, for example, mentoring or face-to-face/ email/telephone support.

Public Education and External Affairs: Dr Mike McClure was appointed as Director of Public Education and Chairman of the Public Education Committee in 2002. Mike made a significant personal contribution to the Partners in Care campaign, and in particular produced an exceptionally comprehensive training package about carer issues for use by mental health professionals. More recently, Mike has been advising the Images of Psychiatry campaign Perceptions' of Psychiatry working group. The College is grateful for everything he has done for us over the past 3 years, including chairing the Public Education Committee and fielding the increasing number of media enquiries which the College receives.

The Public Education Editorial Board, chaired by Dr Philip Timms, continues to produce award-winning mental health information for the general public which is now available in many other languages, including Arabic, Chinese, Hindi, Persian, Gujurati, French, Russian and many others. We are very grateful to all the members of the College who have voluntarily committed their time and energy to producing new materials and in translating them.

Dr Peter Byrne, who was previously very active in the Changing Minds campaign, will today be taking on the new role of Associate Registrar, Public Education and Patients and Carers. I very much look forward to working with him in developing our media and antidiscrimination work and in building our relations with users and carers across the College.

Dr Afzal Javed steps down as Deputy Registrar who has worked so tirelessly with Affiliates and Staff Grade Doctors. The firm foundation he has set will now move into the role of Associate Dean.
Dr Javed has also worked tirelessly developing the involvement of users and carers across all College work.

With our recent report on the way forward for user involvement in the College we are now completing a costing for all user/carer involvement so that we can, with Dr Peter Byrne, take this initiative forward

It has been particularly helpful to have direct user and carer involvement on the CEC.

Policy: Council Reports, Policies, Occasional Papers, suggestions arising from CEC Away Days about possible policy research unit at RCPsych

1. First I would wish to thank Dr Julian Beezehold for all the work he has undertaken in busy times while Associate Registrar leading on Policy and wish him well with his continuing work both clinically and on policy in Europe

2. Dr Ola Junaid has been appointed to start as Associate Registrar Policy starting in the summer.

3. During the process of College committees restructuring it appears to me that much of the work carried out by the Public Policy Committee appeared on the CEC agenda. My view is that much of this work should be carried out via the English Policy Committee (EPC), the Divisional structures in Wales, Scotland, Northern Ireland and Ireland overarched by the Central Policy Committee. Chairs of Divisions and Faculties have had definitely nominated very able members and fellows from their executives and constituencies to serve on policy committees and this continues to be the case.

4. We are undertaking a root and branch review of all Council Reports prepared by the College to analyse how these reports arose, what has triggered them, what purpose they have had and continue to serve, and how they are used by the Members of the College and externally by mental health service professionals, and policy makers.

Specific projects are ongoing on Sponsorship and Risk.

Being a professional implies belonging to our community of practice, in which we are all active participants. It behoves us therefore not just to be an organisation with a memory, but one that shares our extant pooled knowledge and skills more fully in order to more effectively shape policy across the field of all health, mental health, social care and learning disability.

\section{Report of the Treasurer - Professor George Ikkos, and the approval of the summarised Annual Accounts for 2006}

It is an honour to present to the Annual General Meeting my first annual report as Honorary Treasurer. It is also a particular honour to have had and continue to have the opportunity to work closely with the President, Professor Sheila Hollins, and other senior officers of the College and be inspired by their hard work and dedication to the College's values.

During the past year the College has been in a strong financial position. This has not always been the case. The current strength is a testament to the efforts of my two predecessors, Professor Israel Kolvin and Dr Fiona Subotsky, each of whom served 7 years, working effectively with a succession of Presidents, College Officers and members and their representatives.

The current college position is also testament to the Chief Executive, Mrs Vanessa Cameron and her staff. In addition to Mrs Cameron I wish to highlight the excellent support I have received from Mr Paul Taylor, Head of Finance, and his staff and Ms Liz Atkinson, Membership Manager. I have been particularly impressed by the College readiness to receive its auditors this year, particularly as this has been the first year we have presented our accounts in line with the Charity Commission's new Statement of Recommended Practice (SoRP).

Data presented in accordance with SoRP has been summarised in charts 1 and 2. SoRP recommends that the College accounts are presented in a way that reflects the College's objectives.

The Royal College of Psychiatrists is a charity. The College's charitable aims are to promote mental health by:

- setting standards and promoting excellence in mental healthcare

Chart 1

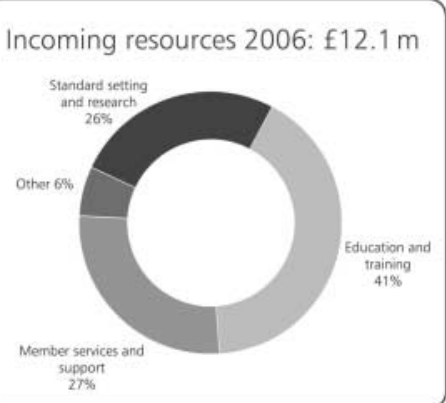

Chart 2

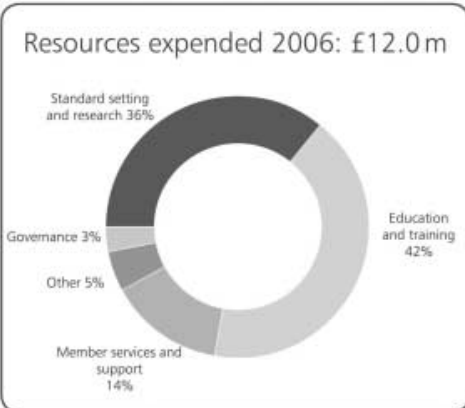


Chart 3

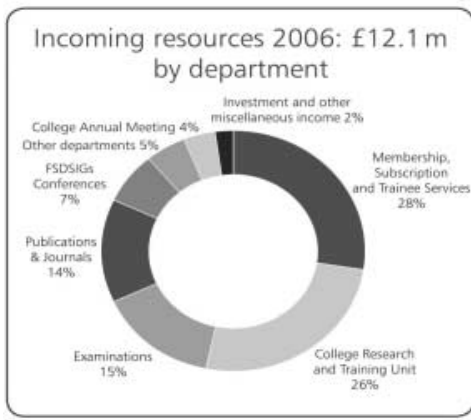

Chart 4

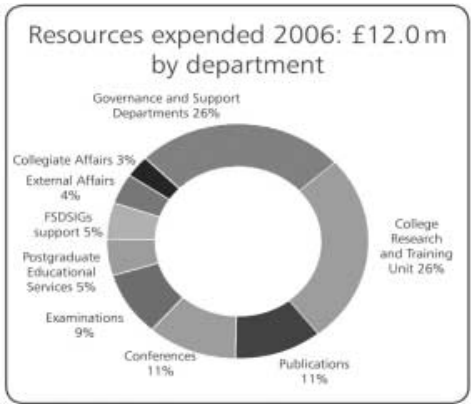

- improving understanding through research and education

- leading, representing, training and supporting psychiatrists

- working with patients, carers and their organisations

The same data presented in charts 1 and 2 may be presented differently and in more detail with respect to specific College activities and departments as in charts 3 and 4 .

The College has capital assets to the value of $f 2048000$ and liquid assets to the value of $£ 4630000$. Of the liquid assets $f 2014000$ is in the 'New Building Fund' and $£ 130000$ in the 'Development Fund'.

Examples of successful activities that expenditure has allowed the College to achieve include the following

- A Health Foundation report has singled out the Royal College of Psychiatrists as exceptional in its commitment and achievement in health services research and the College now has a new Centre for Quality Improvement.

- Financial strength has allowed the establishment of an Academic Faculty within the College and the conversion of the Eating Disorders Special Interest Group to a Section.

- Staffed offices have been established to support Division activities in all Countries of the United Kingdom, all English Regions and the Republic of Ireland.

- A review currently being carried out suggests that the College spends more than $\mathrm{f} 40000$ annually on User and Carer involvement. Of this more than f25 000 is through the College Research and Training Unit and more than $\mathrm{f} 7000$ through the Special Committee for Users and Carers.

A number of financial challenges lie ahead.

The current lease of the College headquarters in Belgrave Square, London, is due to expire in 2034. The Central Executive Committee has agreed that the College conducts an options appraisal, which I propose to fund through the 'New Building Fund'.

The British Journal of Psychiatry currently generates a large income from subscriptions, reprints, rights sales, and advertising. This income is under longterm threat as a result of the pressure from research funders to move towards open access. The College Education and Training Centre was created within the College Research and Training Unit to develop alternative sources of income and its performance remains under review.

Within the current financial constraints of the NHS, funds available to trusts for investment in the College Centre for Quality Improvement networks remain constrained. Trusts often express interest in joining the College Centre for Quality Improvement networks but funding limitations place membership lower on their priority list.

Another uncertainty is the number of people that may be sitting the Membership examination in the future. Having gone through a period of unprecedented growth the number of examinees and our total membership itself are unlikely to continue growing at the same rate, at least in the UK.

The current membership of the College is approximately 12900 , the highest ever. Of these 8800 are Members (MRCPsych) and 2435 Fellows (FRCPsych). Pre-Membership Psychiatric Trainees total just under 1000 and other grades, including Affiliates and International Associates make up the remaining number. The current contribution of membership fees to College income is somewhat less than $30 \%$. This is consistent with historical trends.

Despite the above threats and in view of the fact that Fellows, Members and trainees in the United Kingdom are facing unprecedented challenges (including financial pressures because of the current NHS finance climate, Primary Care Based Commissioning, New Ways of Working and Modernising Medical Careers) I am pleased to confirm that the Central Executive Committee has agreed to the Finance Management Committee's proposal to limit the increase of fees next year to $1.5 \%$ (despite inflation running significantly higher). I feel confident that such a modest increase will not place at risk either the charitable activities of the college or the salaries and benefits of staff.

\section{General Business}

The new fees and subscription rates from 1 January 2008 were approved: Proposed - Professor Hamid Ghodse, Seconded Dr Roger Banks.

The re-appointment of Buzzacott as Auditors of the College to hold office until the next Annual General Meeting was approved: Proposed - Dr Roger Banks, Seconded - Professor Greg O'Brien.

\section{Changes to the Supplemental Charter}

The following amended Resolution was discussed and carried unanimously: proposed by Professor Hamid Ghodse and Seconded by Dr Tony Zigmond.

That the Bye-laws of the College be amended, revoked and added in accordance with the copy thereof containing such amendments, revocations and additions sent to the Members with the notice of this meeting provided that such amendments, revocations or additions shall not take effect until the same shall have been approved by the Privy Council and provided further that the Central Executive Committee of the Council shall have authority to approve any further amendments required thereto by the Privy Council.

The Resolution was approved unopposed.

The President thanked the Officers who were standing down and there being no further business, the meeting closed.

\section{Presentation of Honorary Fellows for 2007 at the Presentation Ceremony held on Thursday 21 June, 2007}

\section{Lord Denis Victor Carter} (Introduced by Dr Tony Zigmond) You will appreciate that I have very mixed emotions delivering this citation. Lord Carter died last December. He emailed me on the 22nd November:

DearTony, I have received the invitation for the award of the Honorary Fellowship which I have accepted with alacrity. It is a great honour and I am most grateful to you for putting my name forward. With my best wishes and repeated thanks. Denis

Lord Carter's working life was in the field of agriculture. While I am told that he contributed a great deal in this area it is not that work which leads to the current 
award. This is for his commitment, personally and through his expertise and energy in managing parliamentary processes, to improving the lot of people with disabilities.

I first met Lord Carter over dinner prior to my giving evidence to the Joint Select Committee scrutinising the then draft Mental Incapacity Bill, which he was to chair. I was struck not only by his knowledge and understanding of the issues (which showed my ignorance of his work, for example that in 1988 he had become Executive Producer to LINK television for people with disabilities) but by his willingness to explain to me how to make the most of the pre-legislative scrutiny process. He went further - he arranged for me to be asked the questions to which I wished to give answers. This was invaluable in ensuring that the College's views were presented properly for consideration by the Committee. However, it was his decision that the committee was to take evidence from the whole range of people who would be affected by the legislation that stands out. A number of people with a learning disability, I think for the first time, were given, and took, the opportunity to give oral evidence to a Select Committee of Parliament. While I have no doubt that the Committee's deliberations benefited from hearing their views, what a valuable lesson it was for all of us who work with people with learning disabilities.

Those who followed the issue will know that there was some significant opposition to the Bill, due to a fundamental misunderstanding on the part of some people as to its purpose, but Lord Carter steered its passage through Parliament with skill and expertise, with the majority of recommendations made by his committee now incorporated in the Mental Capacity Act.

Lord Carter also chaired the draft Disability Discrimination Bill, again taking evidence from, among others, the Royal College but also, more importantly, from disabled witnesses. Indeed, he was so insistent upon this that the Committee left Parliament in order to take evidence from a disabled witness who was unable to travel to Westminster. Again his skill with Parliament processes is evident from the fact that the majority of his Committee's recommendations were accepted by government.

Lord Carter also played an invaluable part as a member of the prelegislative scrutiny committee for the draft Mental Health Bill. One of his frequently expressed concerns was the relationship between the Mental Health Bill and the Mental Capacity Bill. The Bournewood gap was replaced by the Carter gap, or more accurately, the Carter overlap. I suspect this will prove the more enduring problem.
It would not do him justice to suggest that his contribution was limited to parliamentary committees. He gave unstinting help to the College and through us, to our patients. He was a lovely man and I miss his support and guidance.

Lady Carter, I am delighted to say, is here to accept the Honorary Fellowship on Lord Carter's behalf and wishes to say a few words.

\section{Professor Anthony Ward Clare, FRCPsych (Introduced by Dr Jane Marshall)}

Dr Anthony Ward Clare was born in Dublin in 1942. Schooled by the Jesuits at Gonzaga College, Dublin, he went on to study medicine at University College Dublin (UCD), qualifying in 1966. While at UCD he was Auditor of the Literary and Historical Society.

His early training in psychiatry took place at St Patrick's Hospital, Dublin - the hospital founded by Jonathan Swift, Dean of St Patrick's Hospital - where an early formative influence was Professor Norman Moore. His potential recognised, he was advised to seek further training 'across the water' at the Maudsley Hospital in London. He worked at the Maudsley and Institute of Psychiatry (IOP) with a veritable 'who's who' in psychiatry, his peers including such eminent psychiatrists as Robin Murray, Anthony Mann and Paul Mullen. This academic setting provided further formative influences in the persons of Michael Shepherd, Aubrey Lewis, Denis Leigh, D. H. Davies and Griffith Edwards. In 1976, as a 33 year-old honorary senior lecturer, he published Psychiatry in Dissent.

Professor Clare worked at the IOP General Practice Research Unit with Michael Shepherd and Anthony Mann until 1983, when he was appointed Professor of Psychological Medicine at St Bartholomew's Hospital, London. He remained at Barts until 1988, when he returned to Dublin to take up the position of Clinical Professor of Psychiatry at St Patrick's Hospital.

Over the years Professor Anthony Clare has managed parallel careers - as a clinician and medical director, academic and head of department, writer and broadcaster.

As a clinician he has always been warm, caring and empathic, yet astute and grounded in a formidable knowledge base. Those who trained at Barts have fond memories of the Thursday departmental academic meetings which took place at the Robin Brook Centre. Professor Clare encouraged debate and discussion, and his fluency, critical thinking and analysis were compelling and often astounding. The meetings started at $5 \mathrm{pm}$. By $7 \mathrm{pm}$ we had usually repaired to the adjoining bar where the lively debates continued, often drawing in medics from other fields. Although very busy, Professor Clare was a keen mentor of senior registrar research and we regularly met as a group around a large table in his office to present and discuss proposals, research in progress and results. One never felt intimidated at these meetings: he managed to bring out the best in everyone.

Professor Clare's research can be divided up into three eras - the IOP, Barts and St Patrick's.

Academic papers he composed in the 1970s included such varied subjects as alcoholism and road accidents; mental illness and the Irish emigrant; therapeutic and ethical aspects of electroconvulsive therapy; a defence of compulsory psychiatric intervention; ethical issues in psychiatry; the training of psychiatrists also the design, development and use of a standardised interview to assess social maladjustment and dysfunction in community studies. This was the decade in which he wrote Psychiatry in Dissent, arguably the work for which he will be best remembered.

In the 1980s the research and publications continued: depressive disorder in primary care, with Russell Blacker; the epidemiology of minor psychiatric disorder; the premenstrual syndrome; the development of a self-report questionnaire to identify social problems, with Ros Corney; doctors' double standards on alcohol, with Fiona Adshead.

Papers in the 1990s included many neuroendocrine studies of obsessivecompulsive disorder and depression, with Irish colleagues such as Ted Dinan, Jim Lucey, Veronica O'Keane, Conor Farren and Gerry Butcher. There were papers on the fatigue syndromes occurring after infections mononucleosis with Professor Peter White and colleagues from Barts; also on the relationship between sexual abuse in childhood and adult depression and the social correlates of suicide in Ireland from 1945-1992.

Anthony Clare published Psychiatry in Dissent: Controversial Issues in Thought and Practice in 1976 when he was a 33year-old research worker at the Institute of Psychiatry. This was a reasoned response to the vociferous critics of psychiatry in the 1970s: Szasz; Laing and Foucault. It had an enormous impact, and is arguably one of the most influential books on psychiatry published in the last 35 years, inspiring a generation of doctors to enter psychiatry. Professor Simon Wessely chose it as the first of his '10 books' in a 2002 British Journal of Psychiatry feature, commenting that it 'was a dammed good read' but also that it was Anthony Clare who persuaded him that psychiatry was worthwhile and inspired him to pursue a career in psychiatry. 
In September 2005 two Irish psychiatrists, Brendan Kelly and Larkin Feeney, wrote a paper for the Psychiatric Bulletin reviewing the contemporary relevance of Psychiatry in Dissent on the 30th anniversary of its publication. They noted that the importance of Professor Clare's defence of clinical classification has been demonstrated again and again, particularly in the context of the labelling of political dissidents as mentally ill. Many of the issues explored in Psychiatry in Dissent remain relevant today. Anthony Clare was an early advocate of evidence-based psychiatry.

Professor Clare has written numerous other books, both academic and popular I shall mention but one here: Depression and How to Survive it, published in 1994 with Spike Milligan as co-author.

In the 1970s Anthony Clare began to make regular Radio 4 appearances on Stop the Week, a Saturday evening miscellany of satire, topical issues and music. He remained a regular on the programme until he returned to Ireland in 1988. Michael Embers, who produced that programme, went on to become producer and editor of In the Psychiatrist's Chair which was first broadcast on Radio 4 in 1982. In the Psychiatrist's Chair became a hit and made Anthony Clare a household name. Over the years he interviewed people as varied as R.D. Laing, Esther Rantzen, Paddy Ashdown, Dame Janet Baker, Stephen Fry and Clare Rayner. These interviews were published as transcripts with commentaries (Vol 1: 1984, Vol 2: 1993, Vol 3: 1998). It is in reading these commentaries that one gets a glimpse of the man himself. For instance, in the commentary on Ann Widdecombe he notes the certainties of her religious views and her impatience with his 'anchorless' position. He is tempted to quote his heroes, Chekhov, Orwell and MacNeice, to her.

Anthony Clare then went on to present All in the Mind on Radio 4, travelling over to London once a week to record it. This he did until fairly recently.

So, Anthony Clare:

- an Irish psychiatrist who has been described as the most influential British psychiatrist of his generation;

- a psychiatrist who is interested in people and who has continued to practise the art of psychiatry, all the while grounding this in the evidencebase;

- a psychiatrist who has inspired a generation of young doctors to take up psychiatry as a profession

- a psychiatrist who became the acceptable voice of psychiatry;

- a psychiatrist who wrote a book 30 years ago that still speaks to us today;

- a psychiatrist who has sought to understand the relationship between psychiatry and society.
There are many facets to Anthony Ward Clare - the paradox being that this very public psychiatrist remains at heart an intensely private man.

The College is justly proud of you and your manifold achievements for psychiatry, and has great pleasure in awarding you this Honorary Fellowship.

\section{The Rt Hon the Baroness Hale of Richmond, DBE, PC} (Introduced by Professor Sue Bailey) Justice and equality in mental health law and beyond:

The life and times of the Rt. Hon the Baroness Hale of Richmond DBE, PC, FBA, a Lord of Appeal in Ordinary, or as I first encountered Baroness Hale, Brenda Hogget, Lecturer in Law at the University of Manchester. She was then, and is now, at the forefront of Human Rights - basic rights for all human beings whatever 'their human condition'.

Mental health law is a perpetual struggle to reconcile three overlapping, but often competing, goals - obtaining access to the services people need, safeguarding users rights while protecting the public.

Brenda Hale became the UK's first woman Lord of Appeal in Ordinary - the equivalent of a Supreme Court Justice - in January 2004, after an outstanding career as an academic lawyer, law reformer and judge.

After graduating from Girton College, Cambridge in 1966, she taught Law at Manchester University from 1966 to 1984, also qualifying as a barrister and practising at the Manchester Bar. She specialised in family and social welfare law, publishing textbooks on mental health law, parents and children, the family, law and society, women and the law. Her many other publications include the 1995 Hamlyn Lectures, From the Test Tube to the Coffin - Choice and Regulation in Private Life.

In 1984 she was the first woman appointed to the Law Commission, a statutory body which promotes the reform of the law. The work of her team led, she modestly states in biographical details, to the Children Act 1989 the Family Law Act 1996. I believe her main achievement was the Children Act 1989. This brought together the work of the Law Commission team she led on the private law - custody, access and guardianship - and the work of the government Review of Child Care Law on which she also served. Bringing together the two areas of law resulted in the development of the present family justice system and the acceptance of the importance of inter-disciplinary understanding in child protection and family law.

Her work, she again modestly states, led to the Mental Capacity Act in 2005. In reality the mental capacity project was a huge undertaking, involving four consultation papers before the final report with draft Bill, many group discussions with stakeholders from across health professionals, lawyers, and users/families. In 1994 she became a High Court Judge, in 1999 only the second woman Lady Justice in the Court of Appeal of England and Wales, and in 2004 the very first woman to become a Law Lord in the House of Lords.

Among her many other interests, she has been a founder member of the Human Fertilisation and Embryology Authority, Chair (and now President) of National Family Mediation, President of the Association of Women Barristers, and President of the United Kingdom Association of Women Judges. She spent 15 years as a managing trustee of the Nuffield Foundation supporting research and practical innovation in those areas. As a judge in the Family Division most of her work was to do with children and she still tries hard to promote their interests from the appellate committee of the House of Lords, with a relatively recent case upholding the measures to protect child witnesses.

She retains her links with the academic world, principally as Chancellor of the University of Bristol and as visitor of her old College, Girton. She holds several honorary degrees and is also an Honorary Fellow of the British Academy.

She is married to Dr Julian Farrand, a distinguished academic lawyer and former insurance and pensions ombudsman, and has one daughter, three stepchildren, two grandchildren and five step-grandchildren.

In conclusion, to return to Basic Human Rights, Baroness Hale has been central to moving forward:

- The idea that people with menta disorders and disabilities should be enabled to receive the treatment and care they need.

- That Human Rights apply to all people, without discrimination on grounds such as sex, racial or ethnic origin, religion, membership of a particular religious or social group, or the nature of their disability.

- The emphasis that is upon enabling not enforcing: a person's right to choose what may be done to his body or his mind remains intact unless, and until, it is taken away in accordance with proper processes of law.

- That although enforcing may be part of enabling, it should be carefully controlled and applied much more narrowly than the availability of treatment and care. The minimum criteria for an acceptable enforcement process are:

- logical and defensible grounds for intervention

- a fair process which enables the contrary case to be put and heard, and 
- appropriate and humane conditions of treatment and care.

Underlying and overriding all of these is respect for the essential dignity of all human beings.

In 2003, awarded the Philippe Pine Prize, Baroness Hale told her audience in Sydney, referring to the European Convention on Human Rights, that

'The Convention is a living instrument. This gives me hope that, despite all the limitations and frustrations, we can continue to use and develop it to respect the inherent dignity of all human beings'.

Madame President, Baroness Hale is indeed the living instrument through which our mental health users of all ages and our most vulnerable children have been given the chance to have their inherent dignity respected. It is therefore my privilege to present Baroness Hale to you to receive the Honorary Fellowship of The Royal College of Psychiatrists.

\section{Dr Sheila Mann, FRCPsych} (Introduced by Dr Mike Shooter)

The last time I stood on this stage, two years ago, I wondered about the nature of wisdom and the difficulty of pinning it down. Today I can give you the answer - it is called Sheila Mann.

When I rang Sheila to tell her that I had been given the honour of citing her for the Honorary Fellowship, she said it was 'all such a fuss ... I don't deserve to sit amongst them... a Lord, two Professors and a Judge ... I'm just a doctor.' Well that is exactly why you do deserve to sit here, Sheila; you represent what the wise doctor is and which we all strive for, in all its components.

First: knowledge. Sheila's academic career has been exemplary. She was educated at King Edward VI High School for Girls in Birmingham, which my wife (who like all good Welsh people was born a Brummie) tells me is the best school in the UK. She qualified as a doctor at Birmingham in 1965, having collected distinctions in Medicine, Surgery and Obstetrics and Gynaecology, the Queen's Scholarship and two clinical prizes on the way.

Not surprisingly, she was 'kidnapped' immediately by the Bethlem Royal and Maudsley and spent three decades in lectureships and research posts there, at the Institute of Psychiatry, at University College London, at the University of Bristol, St Bartholomew's Hospital and the Medical Research Council, looking in particular at psychiatric problems in a cohort of the National Survey of Health and Development. She has been a member of undergraduate selection panels, an examiner for Final MB, an examiner for the Diploma in Geriatric Medicine of the Royal College of
Physicians, and a Senior Registrar tutor and training scheme organiser.

Second: the application of that knowledge in clinical skills. After her training posts at the Bethlem Royal and Maudsley, Sheila became a Consultant, at first in General Psychiatry, then in General Psychiatry with a special interest in the elderly, and finally in her chosen specialty - Psychiatry in Old Age. She has worked successively for Camden and Islington Health Authority (at Friern and University College Hospital); for Bristol and Weston Health Authority and Frenchay Health Authority; for St Bartholomew's Hospital and for North East Essex Mental Health Trust - now the North Essex Mental Health Partnership. Her clinical acumen has been treasured everywhere.

Third: management of those skills, in her own work and that of others. Sheila has risen from Secretary of the Junior Common Room at the Bethlem Royal and Maudsley and junior staff representative in their Medical Committee (a bear pit if ever there was one) to being a member of the Council and Governor of Barts, and Medical Director, Chairman of the Medical Staff Committee, Trust Medical Advisor and Vice Chair of the Medical Advisory Committee in North East Essex. In between times, she has been a member of countless Hospital Medical Committees, Ethical Committees, management groups and integrated planning groups plotting relocation and provision of services all over the UK. In all of this, Sheila has walked the tightrope with skill and sensitivity between management of services for the common good and representing the proper grievances of individuals within them. And I bet she was Head Prefect at school too!

Fourth: national leadership of her profession. Sheila's progress through the College sounds like a roll-call of almost everything it has been possible to be over the past 30 years. Chronologically, she was a founder member of what were the groups, then sections, then faculties of Psychiatry in Old Age and Social and Community Psychiatry. She was a member of the Working Party on Epidemiology and Applied Social Research and of the Working Party of Trainees of the Education Committee - ah the days of the working party! She was Sub-Dean and a member of Council and the Executive and Finance Committee 'in various capacities'. She was Chairman of the Steering Committee for ECT, an elected member of the Joint Committee on Higher Psychiatric Training and its many subcommittees, a member of the executive of the Southwest Division, and a member of the Board of Examiners. What a list!

All this culminated in Sheila becoming Chief Examiner (1990-1994), College Revalidation Lead (1999-2003), Vice President with special responsibility for clinical governance (1999-2001) and Chairman of the Special Committee on Clinical Governance (2000-2003). She was a member of the Lord Chancellor's Consultative Forum and (whisper it very quietly) of the Delivery Board of Modernising Medical Careers - not her fault! If there was a difficult job to be done in our profession, at some point we would all come round to wondering if Sheila could take on just one more responsibility.

Fifth: doing all that high-profile stuff without forgetting your local roots. Sheila has fought for her geographical regions as a member of their Divisional Executives, as regional specialty representative, as a member of the regional advisory committees in Geriatric Medicine, of regional Higher Training Committees, of regional advisory panels on the Mental Health Act and the Advisory Committee on Distinction Awards. It is rare to meet someone of such national standing who has remained so loyal to her local, regional cause.

Sixth: taking care to pass on all that accumulated wisdom to the next generation and for posterity. Over 30 years, from the early 1970's to the present day, Sheila has produced seminal publications over the whole range of psychiatric practice and in her own specialty: 'Doctors and Their Health'.

Which takes us to that aspect of wisdom for which, perhaps, we admire Sheila most: the emotional, intellectual, moral and even physical courage to carry what you have learnt and come to believe in, out into hostile territory - in Sheila's case the General Medical Council! She has been an Examiner and Assessor on the GMC's Health Committee for 12 years for heaven's sake. She has been a Health Screener for 8 years, Chairman of the Working Group on Assessment in Psychiatry, an Appointed Member for 6 years (Associated to the summer of next year), on the GMC's Overseas and Registration Committees for 6 years, the Committee on Professional Performance for 4 years, and the GMC representative on the Working Group on New Roles for Psychiatrists and the Specialist Training Authority.

Everyday that blue bag arriving, bearing an onerous, never-ending, thankless workload for a pittance of pay. Standing up before physicians, surgeons and GMC staff, surrounded by lawyers and in the shadow of public and politicians baying for the tighter regulation of doctors, stating clearly what has to be said on behalf of those with mental health problems, balancing the protection of the public with a proper recognition of those problems and the right to return to jobs wherever possible. Sheila has championed the cause of such doctors everywhere, in every specialty, in the teeth of everything from indifference to outright opposition. 
For that, it is not just the Royal College of Psychiatrists but the whole of Medicine that is in her debt.

Finally, as a post-script but an important one: the ability to keep all that, as we would want with our patients, in the perspective of life as a whole. Sheila is, quite rightly, a private person but I can tell you from personal experience that she has a love of fast cars (a Porsche and a Mini Cooper, I think, at last count) and drives them, even when partially disabled by a wrist splint, at breakneck speed! She is fun to be with... as long as you survive her company.

President, I cannot think of anyone who so embodies the concept of wisdom as Sheila Mann. She is not 'just a doctor' but a just doctor, dedicated to the pursuit of fairness. I commend her to you as a most worthy Honorary Fellow of Our College.

\section{Professor Bruce Singh, MBBS, PhD,} FRACP, FRANZCP (Introduced by Professor Dinesh Bhugra)

Professor Bruce Singh has been Cato Professor and Head of the Department of Psychiatry for the past 16 years and is currently also Deputy Dean of the Faculty of Medicine, Dentistry \& Health Sciences at the University of Melbourne. He is internationally renowned in the field of psychiatry for a number of activities, including teaching, research and policy development.

Having been born in Sydney, he grew up in Fiji before training at the University of Sydney in Australia. He has worked at the Universities of Newcastle, Sydney, Monash and Melbourne. In addition to his Chair he is also the Clinical Director of the North Western Mental Health Programme (one of Australia's largest mental health programmes which provides a service to over one million people in northern and western Melbourne). He was, for 9 years, Associate Dean (International) of the Faculty of Medicine, Dentistry \& Health Sciences. In addition he has served on several occasions as Chief Policy Adviser to the Mental Health Branch, Victorian Department of Human Services and the Minister for Health and was one of those responsible for developing the Australian National Mental Health policy and plan. He has been President of the Pacific Rim College of Psychiatrists and is currently the World Psychiatry Association Zone 18 Representative, within the Royal Australian and New Zealand College of Psychiatrists over a 20 year period and has had various roles, including Chairman of the Fellowship Board, where he was responsible for the Committee for Examinations, Committee for Training and the Committee for Training in Child Psychiatry. Prior to this he also chaired the Committee for Examinations (formerly Censor-in-Chief) and its sub-committees for written examinations and exemptions and was an ex officio member of the Executive Committee and General Council. Prior to moving to the University of Melbourne he was Foundation Professor of Psychological Medicine, Monash University, Royal Park and Alfred Hospitals, Melbourne.

He has edited and contributed to six books including Foundations of Clinical Psychiatry Textbook (3rd edition), Mental Health in Australia (2nd edition) Understanding Troubled Minds; now he is completing a book on the history of psychiatry in Victoria. His contributions to research in Australia and elsewhere in collaboration with international groups, such as the Institute of Psychiatry in London and Harvard University, have been immense. He has published widely and he has supervised the theses of many internationally well established academics. In 1993 Professor Singh was awarded the Centenary of Federation Medal and in 2007 the Membership of the Order of Australia by the Australian Government for his contribution to psychiatry. In 2006 he was made an International Fellow of the American Psychiatric Association (APA) and in 2007 was awarded the Meritorious Service Award of the Royal Australian and New Zealand College of Psychiatrists (Victoria Branch).

doi: $10.1192 / \mathrm{pb} .31 .12 .470$ 